\title{
Palestine Exploration Quarterly
}

\section{Notes and Queries}

\section{Charles Fox}

To cite this article: Charles Fox (1893) Notes and Queries, Palestine Exploration Quarterly, 25:1, 67-69, DOI: 10.1179/peq.1893.25.1.67

To link to this article: http://dx.doi.org/10.1179/peq.1893.25.1.67

曲 Published online: 20 Nov 2013.

6 Submit your article to this journal

LII Article views: 4

Q View related articles $ک$ 
than the one afforded by the map of Ezekiel when interpreted by a 21-inch cubit.

Seeing the result that appeared in symbolic measure, I cannot but suppose the conclusions correct so far. For here an almost perfect quotient is afforded. Hence the errors in latitude of places still evinced is either, $I$ conceive, imaginary-due to errors in surveying or in tixing sites-or owing to mistakes in my own application of distances to latitudes. Let us also add that, granting the necessary truth of the result which gives 7-cubed, it follows that 25 inches is the true sacred cubit, and it can be precisely determined by this singular argument, which is, at least, not one to be lightly set aside. Some may dispute its cogency, but it appears a sound one to me.

November, 1892.

\section{NOTES AND QUERIES.}

\section{Ry Charles Fox, M.R.C.S., F.S.S.}

I. TAKE this channel to make two or three enquiries and animadversinns relative to particulars carefully and laboriously supplied, and which, from certain clues my researches on the Great Pyramid, Tabernacle, and Temple have supplied me with, I deem to be of much interest. It is surprising, and should ever be borne in mind by explorers and on the coming to knowledge of fresh antiquities, how there is nothing scarcely which one day, in the light of explanations not yet reached or of other facts not yet discovered, may not prove to be of interest we should now never suppose. Thus monuments, larger and smaller, were for ages neglected because they were thouglit meaningless or, at best, enigmas, which are now found to supply confirmation of History or mystery, or to be links of great value, or serve to establish the integrity and authenticity of Holy Writ. What a striking existence of this is the Boundary Stone of the Cities of Refuge, a small relic and seemingly unintelligible at first! and had not the very spot it was found in been noted, we should have lost the deeply interesting and single evidence of the truth of the Bible record as to their extent. Again, the ancient sarcophagus which is found to contain the expression "Under the Sun" in its long and apparently useless inscription has affirmed the Oriental accuracy and antiquity of the Ecclesiastes some had denied. So that it is most desirable every fact of location, name, number, \&c., as well as marking and form, in new finds should be observed, since all may be found to have a bearing on sacred things, whether more or less directly, and many to be such themselves. For it is to be considered always that we know not what new explanations and theories will be reached, especially as further facts are obtained, and that then things before unintelligible, and indeed uninteresting, and details long held of no consequence and overlooked may suddenly be of 
great interest. These may then even serve to establish or to answer a new hypothesis, or to solve a new question, or may throw complete light unexpectedly upon some other nonument or some text.

These principles are familiar to the readers of the Quarterly Statements, if they are to anyone; but I judged it would not be superfluous to state them emphatically, to remind those engaged in enquiries and explorations, and all who may fall in the way of new matter, of their importance. For, if not done at the time, the opportunity may be lost for ever to sacred science, whether of mystery, doctrine, topography, or hermeneutics, so that it often rests in the hands of the finder. And it is important for him to remember that it may be long after our time things will be understood which cannot be by us, so that it follows that they are indifferent because we are still ignorant of so much. Knowledge is ever enlarging and bringing new theories, which lead, at lengtb, to the fixing of principles new to us, like the laying of new lines of rail which open fresh domains, and we know not whence the aid will come, any more than when.

\section{Notes and Queries.}

I. Whether G. Post was able to secure and save the two stones he figured in Quarterly Statement, 1891, p. 300, at or from Buswâyeh.

The design on the coffin-lid (?) seems to me of new and extreme beauty -.. a cross figured in palms-not to speak here of its mystical characters, which are not less beautiful as expressing Christ.

This stone, as is stated, may be from an altar. It is probably fuily as likely to be a pavement as a sepulchre stone. It is strikingly homologons in design with the matter referred to next. I conclude it has lost $7 \frac{1}{2}$ inches from one (the left) end, as well as being broken across. Both the stones appear to nie of peculiar interest.

II. B. Schick does not state the general position of the highlymystical and beautiful mosaic he describes and figures in Quarterly Statement of this year, p. 190. It is of great interest to the significance whether it is Oriented, as I have little doubt it is.

I conclude in his picture the lozenges are made too narrow from side to side (as it lies); they are almost or quite square. He states that they are not square, and in figuring the pavement by his description it seems to me they cannot be. This is probably the error in his valuable drawing which he refers to, as compared to a photograph (?).

III. The same explorer does not state, in his account of Gordon's Tomb of Our Lord, the size of the Eastern chamber, as I read. Note, the points of the compass are, by mistake, put wrong ; I assune, north where east should be in the diagram.

IV. The indefatigable Schick, in his plans of the singular Rock tomb at Bethany, p. 249, makes some of the measures not exactly agree with the text.

V. Can anyone state the accurate dimensions of the Chamber in the Sakhra? This hidden place is of very remarkable occult significance, as I 
have demonstrated from what accounts of its size I could gather, for the Sakhra is doubtless the most marvellously interesting relic almost in the globe, and we cannot wonder at the veneration paid to it, though blindly, therefore, by the Mohammedans-in preserving it, enclosing with rails, and making it the centre of their great Dome. As far as I am aware, it has scarcely been minutely enough described-which is the case with many monuments which most of us cannst go and measure for ourselves.

VI. Can anyone say whether a window into' a tomb is very rare, or are there other cases like "Gordon's Tomb" and Conder's in this feature?

\section{MUI) SHOWERS AND THEIR EFFECT ON BUILDINGS IN PALESTINE.}

By the Rev.. J. E. Hanader.

LAST May I happened to spend: a Sunday at Nazareth. About fourteen years had elapsed since I had last visited. the place, and on this occasion I was very much surprised at the change that had during that time taken place in the colour of buildings there. The Protestant Church, for instance, which in 1878 was fresh, white, and conspicuous, had weathered into a light brown or yellowish tint, and was difficult to distinguish from other buildings near it; whilst, from the same causes, it was scarcely possible to recognise the Orphanage of the Society for Fewale Education in the East, situated on the hill-side high above the town, and which, when new, could easily be seen at a great distance.

So struck was I with this circunstance that I nesolived that on my return to Jerusalem I would pay particular attention to the colour of buildings there.

The first discovery I made was that whether or not familiarity breeds contempt, it was certain that in my case it had produced blindress, for it was only now (when my special attention was drawn to the subject) that I noticed, what I had seen thousands of times before and yet never observed, namely - that whilst the city walls and towers were, generally speaking, both externally and internally, grey on their northern and western faces, which are most exposed to rain, yet that their southern and eastern faces, whether external or internal, were of different sharles of tawny yellow, ochre, or brown. Closer examination showed that this remarkable difference of colour in the eastern and southern faces from that of the western or northern was due, not merely to greater exposure to sunshine and protection from rain on the east and south, but to the presence of a curious coating or pigment varying, according to the hardness of the stone it adhered to (or to the angle of protection and corer afforded by projections or buildings near), in the shades of yellow, ochre, and brown ; and further, that these tawny patches of colour are found not only on 